\title{
Learning Model Team Assisted Individualization Assisted Module to Improve Social Interaction and Student Learning Achievement
}

\author{
Rina Novalinda1, Oskah Dakhi ${ }^{2, *}$, Melda Fajra ${ }^{3}$, Azmil Azman ${ }^{3}$, Mardhiah Masril ${ }^{4}$, Ambiyar $^{5}$, \\ Unung Verawadina ${ }^{5}$ \\ ${ }^{1}$ Akademi Refraksi Optisi YLPTK, Padang, Indonesia \\ ${ }^{2}$ Faculty of Computer Science and Information Technology, Universitas Budi Darma, Medan, Indonesia \\ ${ }^{3}$ Faculty of Engineering and Planning, Universitas Ekasakti, Padang, Indonesia \\ ${ }^{4}$ Faculty of Computer Science, Universitas Putra Indonesia, Padang, Indonesia \\ ${ }^{5}$ Faculty of Engineering, Universitas Negeri Padang, 25132, Sumatera Barat, Indonesia
}

Received September 26, 2020; Revised November 24, 2020; Accepted December 6, 2020

\section{Cite This Paper in the following Citation Styles}

(a): [1] Rina Novalinda, Oskah Dakhi, Melda Fajra, Azmil Azman, Mardhiah Masril, Ambiyar, Unung Verawadina "Learning Model Team Assisted Individualization Assisted Module to Improve Social Interaction and Student Learning Achievement," Universal Journal of Educational Research, Vol. 8, No. 12A, pp. 7974-7980, 2020. DOI: 10.13189/ujer.2020.082585.

(b): Rina Novalinda, Oskah Dakhi, Melda Fajra, Azmil Azman, Mardhiah Masril, Ambiyar, Unung Verawadina (2020). Learning Model Team Assisted Individualization Assisted Module to Improve Social Interaction and Student Learning Achievement. Universal Journal of Educational Research, 8(12A), 7974-7980. DOI: 10.13189/ujer.2020.082585.

Copyright $\subseteq 2020$ by authors, all rights reserved. Authors agree that this article remains permanently open access under the terms of the Creative Commons Attribution License 4.0 International License

\begin{abstract}
This research aims to improve social interaction and learning achievement in Computer and Network learning materials in Grade X-9 Vocational High School 1 Padang students using the Team Assisted Individualization learning model with modules. This research is a Class Action Research consisting of two cycles. Each Cycle consists of action planning, action execution, observation, and reflection. This study's subject was Grade X-9 Vocational High School 1 Padang Year 2019/2020, which numbered 38 students. Data sources come from teachers and students. The data validity technique used in this study is a triangulation technique that tests the validity of data by utilizing outside means of data to check or benchmarking data methods. The analysis technique also refers to Miles and Huberman analysis models performed in three components: data reduction, data presentation, conclusion drawing, and verification. Data collection instruments through questionnaires, tests, observations, and interviews. The data analysis techniques used are qualitative and quantitative descriptive analysis. The results showed that the Team Assisted Individualization learning model with modules could improve: (1) social interaction increased from $47.37 \%$ to
\end{abstract}

71.05\%, and (2) cognitive aspect learning achievement by $34.21 \%$ increased to $65.79 \%$. While the affective aspect is learning in (Cycle I) reached the target of 81.58\%.

Keywords Team Assisted Individualization, Social Interaction, Learning Achievement, Module

\section{Introduction}

Education is one of the essential aspects of improving human resources in Indonesia. Many countries' experience shows that quality human resources are more necessary than abundant natural resources with a quality education. Recognizing the importance of improving human resources quality, the government continues to strive for quality education[1].

One of the government's efforts to improve education quality is to make changes to the curriculum. The curriculum is an essential part of education. One of the curriculums used in the learning system in Indonesia is the Education Unit Level Curriculum. According to the 
National Board of Education Standards (2006), the Education Unit Level Curriculum is an operational curriculum developed and implemented in every school or unit of education. In implementing this curriculum, teachers create student self-efficacy by each individual's excellence or uniqueness by learning in the classroom through various innovative, challenging, and fun learning experiences[12].

In the Education Unit Level Curriculum, computers and networks are among the subjects of Vocational High School. Computer and Network Learning in vocational school aims to give students the ability to: (1). Develop awareness of nature's regularity and beauty as a form of the greatness of the One True God; (2). Fostering of scientific attitudes; (3). Gain experience in applying scientific methods through experimentation; (4). Raise awareness of computer applications; (5). Understand computer concepts and connectivity; (6). Apply computer concepts to solve problems of daily life; and (7). positive attitude towards computers. [4,12].

The learning tools used in Vocational High School 1 Padang have not caused an increase in students' learning interest. The provision of media for teachers to carry out teaching and learning activities has not been maximal. Based on observations made before the action on Tuesday, January 5, 2020, it appears in the classroom, the teacher delivers the material in his conversation, and the students listen. In addition to presentation materials, teachers have not used media that correspond to material characteristics that cause students to become less eager to learn and become less active.

Based on interviews with some X-grade students, computer and network lessons are a difficult lesson. They have trouble understanding the concept. Besides, some students experience problems in counting and memorizing. Some also revealed that the computer and network were abstract. According to the teacher of computer subjects grade $\mathrm{X}$, among the various materials of grade $\mathrm{X}$ even semester, computer and network materials are considered the most difficult.

Computer and Network Materials are materials that require a strong understanding of concepts. If students do not understand the Concept, they will experience difficulties in computer and network-related materials because the network programming materials are continuous. Computer and network materials are difficult because to understand that material, and students need to understand computer and network programming materials that also require high understanding[5,14]. Students who do not understand the material may have difficulty understanding computer and network materials. Therefore, it takes a proper learning model to present this material to achieve the maximum learning goals.

Based on the final repeat of odd semester class $\mathrm{X}$, the average grade $\mathrm{X}-9$ is relatively low at 37.7. The material tested in the semester replay is material related to computer and network material. Thus, if the semester value is low, it is suspected that the class has problems when receiving computer and network subject matter. The average grade $\mathrm{X}$ repeats (odd semesters) can be seen in Table 1 below.

Observations showed that social interactions between high, medium, and low ability X-9 students were not well established, with the results of a pre-action social interaction questionnaire of $47.37 \%$. Most students still have high individualism and don't even care about each other. When assigned assignments by teachers, highly capable students do not guide other students, and for students with insufficient knowledge, there is no willingness to ask students with higher strength.

Table 1. Average Final Replay Value of Semester Class X High Vocational School 1 Padang 2019/2020

\begin{tabular}{|c|c|c|c|}
\hline Class & $\begin{array}{c}\text { Number of } \\
\text { Students }\end{array}$ & Average & Completed \% \\
\hline $\mathrm{X}-1$ & 20 & 56.45 & 9.09 \\
\hline $\mathrm{X}-2$ & 40 & 49.03 & 10.00 \\
\hline $\mathrm{X}-3$ & 39 & 42.90 & 7.69 \\
\hline $\mathrm{X}-4$ & 41 & 43.24 & 7.32 \\
\hline $\mathrm{X}-5$ & 42 & 42.30 & 7.14 \\
\hline $\mathrm{X}-6$ & 42 & 36.40 & 7.14 \\
\hline $\mathrm{X}-7$ & 44 & 39.30 & 6.82 \\
\hline $\mathrm{X}-8$ & 40 & 40.57 & 7.50 \\
\hline $\mathrm{X}-9$ & 38 & 37.76 & 5.26 \\
\hline $\mathrm{X}-10$ & 47 & 32.50 & 10.64 \\
\hline $\mathrm{X}-11$ & 40 & 28.75 & 10.00 \\
\hline $\mathrm{X}-12$ & 46 & 41.33 & 8.69 \\
\hline $\mathrm{X}-13$ & 42 & 39.58 & 9.52 \\
\hline $\mathrm{X}-14$ & 33 & 40.41 & 6.06 \\
\hline
\end{tabular}

UNESCO formulates four pillars of education to deal with and adapt to the rapid development of the world, namely: (1) learning to know, (2) learning to perform, learning to work, (3) learning to live together, and (4) learning to grow in its entirety. One of the essential pillars of education is learning to live together. Learn to live by developing understanding others to know each other and appreciate relevance, implementing joint projects, and learning to resolve conflicts in a spirit of respect for the values of understanding, mutual understanding, and peace[3]. The application of shared learning in the learning process can be a social interaction in students. Social interaction can provide student support and reflection that affect teaching processes and outcomes. Thus the school takes full responsibility for building students' social attitudes by implementing interpersonal communication and group involvement.

From the above problems, it is necessary to improve the quality of social interaction and student learning achievement. As a follow-up to overcome the issues that 
occur, it is essential to conduct action research to enhance learning quality through Class Action Research. Class Action Research aims to strengthen the rationale and appropriateness of teaching and learning practices, strengthen the understanding of teaching and learning practices, and improve the situation or institution in which the course[20,22]. Therefore, Class Action Research is an investigation conducted by teachers in the classroom through self-reflection to enhance their profession so that learners' learning outcomes continue to improve.

The effort that teachers can make to renew learning practices is by implementing Cooperative Learning Models. Cooperative Learning refers to learning methods in which students work together in small groups and help each other in education[6,13,18]. Based on the problems described above, a cooperative learning model is needed that improves not only social interaction but also student learning performance, one of which is to use a Cooperative Learning Model of Team Assisted Individualization (TAI) [23,24,25].

The purpose of Team Assisted Individualization learning is to overcome the difficulty of understanding and solving learning material problems, and group leaders (assistants) who have more knowledge. Students with higher abilities can help their friends who have learning difficulties. Thus, Team Assisted Individualization learning refers more to good social interaction between all learning components so that social interaction between students can be well established and improve learning achievement[15,17,19]. Nneji's research L. (2011) on Team Assisted Individualization mentions that Team Assisted Individualization is an effective method in Basic Computer learning; Team Assisted Individualization can also improve students' learning achievement in Basic Computer learning[9].

In addition to the learning model, learning media is one of the integral components of the learning system. Meaning media becomes an essential component in delivering learning. Judging by its function, teaching materials contain learning messages that are ready to be conveyed to students, so that the teaching materials include teaching media. Teaching materials are specific subject matter arranged systematically and concisely so that the material is easier to understand.

Teaching materials used in Vocational High School 1 Padang in Basic Computer learning in the form of Student Worksheets by the Teacher Deliberation of Subjects in Padang city. The Student Worksheet contains concise material and question training questions and is the only teaching material used. Therefore, other teaching materials are needed to efficiently support learning that contains complete materials to understand the material quickly.

The teaching materials referred to in this study are modules in learning packages that include a series of planned learning experiences and to help students achieve learning goals. Useful learning modules should present teaching materials by the demands of the curriculum, follow the development of Science and Technology, and bridge learning. Previous research mentioned that the Basic Computer concept teaches materials by researchers using more systematic and concise Concepts to make the material easier to understand[10,21,26].

Based on the above description, researchers researched to improve students' social interaction and learning achievement in grade X-9 Vocational High School 1 Padang using a cooperative learning type Team Assisted Individualization (TAI) assisted module. The advantage of module-assisted Team Assisted Individualization learning is to apply student-centered group learning and mentoring between friends where modules serve as providers of the necessary information, as learning materials for students, and as complementary materials with communication. Thus, module-assisted Team Assisted Individualization learning to improve social interaction and student learning achievement.

\section{Materials and Methods}

\subsection{Research Design}

This research is a Class Action Research conducted in two cycles. Class Action research as a problem-solving strategy by utilizing real actions and then reflecting the results of efforts, thereby increasing student learning activities in Social Science learning by applying a cooperative learning model type Team Assisted Individualization[16].

The class action research is divided into four stages: planning, action, observation, and reflection. The class action research model used in this study uses the Kemmis and Mc Taggart models presented in Figure 1.

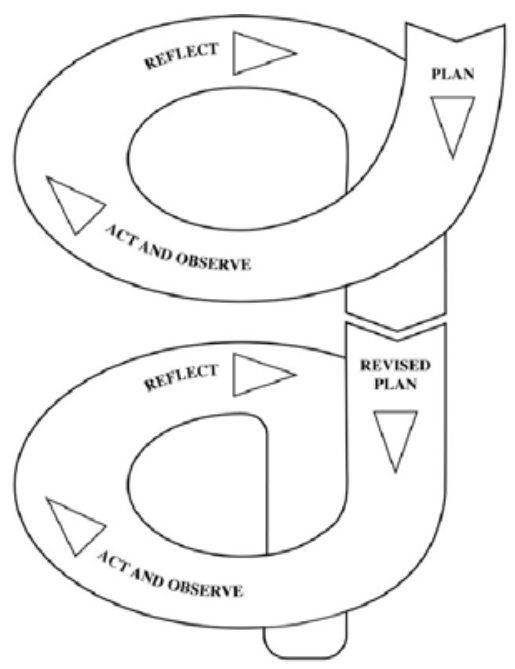

Figure 1. Kemmis and Taggart Model Action Research Design (1992: 11) 


\subsection{Research Subjects}

This research is a Class Action Research consisting of two cycles. The research subjects were grade X-9 students of the Vocational High School 1 Padang of 38 students. The selection of research subjects in this, considering that the subject experienced an identified problem at the time of initial observation and interviews with teachers and students. This research's object is the social interaction and learning achievement of students (affective and cognitive aspects) of the applied learning.

\subsection{Research Instrument}

The data collected in this research are student data reviewed from qualitative and quantitative aspects. Qualitative aspects include observational data, interviews, and questionnaires that describe the learning process in the classroom. The quantitative element in question is the data assessing students' learning outcomes in computer and network materials, covering cognitive and affective aspects, cycle I, and cycle II.

Data analysis in Class Action Research starts from the beginning until the end of data collection. Data from the results of research in the field are processed and analyzed qualitatively. The qualitative analysis in question is analyzed descriptively. The analysis technique also refers to Miles and Huberman analysis models performed in three components: data reduction, data presentation, conclusion drawing, and verification[7]

The data validity technique used in this study is a triangulation technique that examines the validity of data by utilizing means from outside the data to check or benchmark data collection techniques in the form of triangulation of data collection methods[8]. This research used data collection methods through observation, interviews, questionnaires, and tests. By the research design above, the instruments of this research are as follows.

\section{a). Observation Sheet}

The observation sheet is a record that describes the level of activity of students in the learning process. "Observation is a method or method of systematically analyzing and recording behavior by viewing or observing individuals or groups directly"[13]. This method observes teachers' and learners' activities in the learning process if the learning process is effective.

\section{b). Interview Guidelines}

This method obtains data on the problems faced in learning before giving action, including strategies and learning methods used in activities and learners' achievements.

\section{c). Questionnaires}

A questionnaire is a data collection technique done by giving a set of questions or statements to others used as respondents to answer a series of written questions. Respondents here are students who respond or answer the questions provided. The questionnaire used is a questionnaire of social and affective interactions. This questionnaire contains items that will determine the student's response after learning using the Team Assisted Individualization model with the help of modules.

d). Test

The test is to measure students' learning achievement as a follow-up to the learning process. Tests are carried out at the end of each cycle to determine the effectiveness of learning. The test consisted of 10 questionnaires to assess how students mastered the subject matter after applying the Type Cooperative learning model Team Assisted Individualization.

\section{Results and Discussions}

Based on the problems identified before the Action, an appropriate learning model is needed to improve students' social interaction and learning achievement in Grade X-9 of Vocational High School 1 Padang. The learning model used is a cooperative learning model of Team Assisted Individualization (TAI) type with modules on Computer and Networking materials. Tai's learning objective is to overcome the difficulty of understanding and solving learning material problems and the group leader (assistant) who has more knowledge. Students with higher abilities can help their friends who have learning difficulties. Thus TAI learning refers more to the power of good social interaction between all components of learning so that social interaction between students can be well established and can improve learning achievement. Thus, the Team Assisted Individualization learning with modules expected can enhance social interaction and student learning achievement. [10,11].

\section{Cycle I}

Researchers with teachers prepare syllabuses, learning implementation plans, learning media, research instruments, and plan research schedules at the planning stage. The planned study consists of 6 hours of lessons (3 face-to-face), 4 x 45 minutes for material delivery, and 2 x 45 minutes for the cycle I evaluation tests.

Based on the planning of actions that have been done by researchers, then applied in class X-9 Vocational High School 1 Padang. The learning process uses the Team Assisted Individualization (TAI) model; students have eight groups with each group of 4-5 people with one member as an assistant. The initial learning activity is that the teacher gives the student perception in the form of questions related to daily life associated with the material. It aims to explore the student's early knowledge. 
Furthermore, the teacher provides orientation by conveying the learning objectives and learning models at today's meeting. Then the teacher motivates by sharing the benefits of learning the material so that students are eager to follow the learning $[14,15]$.

The core learning activities into three stages: exploration, elaboration, and confirmation, adapted to the syntax of the Team Assisted Individualization learning model. At the exploration stage, teachers facilitate student interaction with teachers, the environment, and other learning resources in Computers and Networks materials (teacher groups). Students also look for information about Computers and Networks materials with reading modules prepared by teachers (creative students). At the elaboration stage, students discuss in groups issues in the form of discussion questions (team study). Students then present the results of a group discussion in front of the class, and other group students respond to the presentation by giving questions or feedback to the group (the entire class unit).

At the confirmation stage, the teacher provides positive reinforcement and feedback orally and in writing about the learning results that have taken place to avoid misunderstandings about the material discussed. In the last activity, the teacher guides students to present the learning conclusions that they have. The teacher's next stage gives a post-test to students who work individually as evaluation (fact test).

At the end of Cycle I, social interaction tests, affective aspect tests, and cognitive aspect tests are performed. The percentage of X-9 graders obtained social interaction test results with completion of $71.05 \%$; affective aspect test results of $81.58 \%$; and the cognitive aspect with a completion percentage of $34.21 \%$. Each element of Cycle I are presented in Table 2.

Based on the overall results obtained in cycle I, there are two indicators on cognitive aspects that have not reached the specified target, namely determining binary numbers and determining the number of client computers in computers and networks. Both indicators' failure is due to the material in hand requiring a deep understanding of concepts in determining binary numbers, calculating computer client numbers, and identifying changes. Besides, the role of assistants that are not yet maximal is also one factor that causes the low reach of these indicators. Therefore, researchers need to take further action by doing learning in cycle II.

Table 2. Achieved Cycle I Success Target

\begin{tabular}{|c|c|c|}
\hline Aspects & Achieved \% & Criteria \\
\hline Social Interaction & 71.05 & Reached \\
\hline Affective Aspects & 81.58 & Reached \\
\hline Cognitive Aspects & 34.21 & Not reached yet \\
\hline
\end{tabular}

\section{Cycle II}

Based on the results of the reflection of the action of a cycle I, planning the implementation of actions in cycle II by changing the discussion group based on the results of cognitive tests cycle I and teacher considerations. Changes in assistants and group members in cycle II improve learning achievement in students' cognitive aspects in achieving predetermined targets. In cycle II, learning focused on competency indicators. Teachers repeat competency indicators on incomplete cognitive aspects, namely determining network binary numbers and determining client IP addresses on the computer and network materials. Group division in cycle II on evaluation results in cycle I. Students who have completed the cycle are distributed into groups to become assistants and help other students. The number of groups in cycle II is the same as the first cycle consisting of 8 groups, and each group consists of 4-5 students.

Implementation of cycle II actions in one meeting with a time allocation of 1 × 60 minutes for learning and 1 x 30 minutes to evaluate cycle II. In cycle II learning, teachers only deliver material with incomplete indicators in cycle I. Cognitive tests are tested at the end of cycle II learning in the form of objective tests of 10 question points. Based on the analysis of the test results of cognitive aspects of cycle II obtained results that students of grade X-9 who have achieved completeness as much as $65.79 \%$. The cycle II test results for cognitive aspects have met the set completion target of $60 \%$ of the completion percentage. The Completeness of Cognitive Aspects of Cycle I as in Figure 2. below.

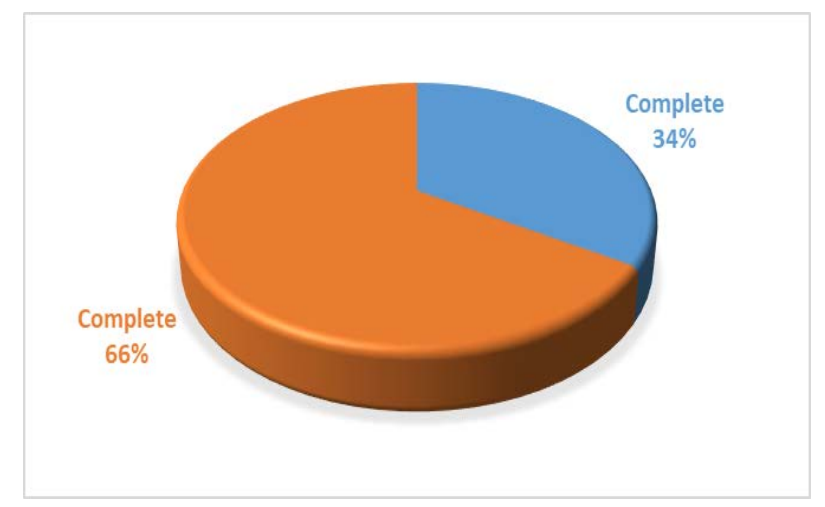

Figure 2. Pie Diagram of The Completeness of Cognitive Aspects of Cycle I

\section{Inter-Cycle Comparison}

The comparison of action results between these cycles aims to determine the improvements in Cycle I and Cycle II. Comparison of action results is only made on cognitive aspects because affective aspects and social interactions have reached the target specified in cycle I. Comparisons between cycles are presented in Table 3 . 
Class action research can be successful if this research has achieved social interaction and learning achievement that includes affective and cognitive aspects. It to be successful so that the learning of the model Team Assisted Individualization assisted by modules can improve social interaction and student learning achievement in computer materials and network-grade X-9 Vocational High School 1 Padang Year Lesson 2019/2020.

Table 3. Comparison of Action Results Between Cycles of Network Programming Materials in High Vocational School 1 Padang Year $2019 / 2020$

\begin{tabular}{|c|c|c|c|}
\hline \multirow{2}{*}{ Aspects } & \multicolumn{2}{|c|}{ \% Achievement } & \multirow{2}{*}{ Criteria } \\
\cline { 2 - 3 } & Cycle & Cycle & \\
\cline { 2 - 3 } & I & II & \multirow{2}{*}{ Reached } \\
\hline Cognitive & 34.21 & 65.79 & \\
\hline
\end{tabular}

Referring to the results of previous research conducted by some research that has been done by Nneji (2011); Rejeki, Guyub, et al. (2013) that there is an increase in student learning outcomes taught using a cooperative learning model type Teams Assisted Individualization. Research results from Setiawan, Martini, \& Mulyani (2015); Fatimah, Saputro \& Agustina (2017) that learning with the cooperative learning model Teams Assisted Individualization (TAI) can improve students' social interactions. The researcher conducted research to improve social interactions and learn through the Cooperative learning model type Team Assisted Individualization with a module. The advantages of TAI learning-assisted by modules are applying student-centered group learning and inter-group guidance. The module serves as an essential information provider, learning material for students, and complementary material with communicative illustrations photos[3,9,16]

\section{Conclusions}

Based on the class action research results, the cooperative learning model of the Team Assisted Individualization can improve social interaction and student learning achievement in computer materials and network-grade X-9 Vocational High School 1 Padang Year Lesson 2019/2020. Implementation of cooperative learning model of the Team Assisted Individualization with modules in grade $\mathrm{X}$ students of Computer Network subjects, implemented in two cycles.

Cycle I obtained the percentage of social interaction completion of students in grade X.9 of $71.05 \%$, and the percentage of completion of affective aspects is $81.58 \%$. The rate of completion of cognitive aspects obtained $34.21 \%$. While in cycle II the test results of cognitive aspects of cycle II increased to $65.79 \%$. Cycle II tests for cognitive aspects have met the set completion target of $60 \%$ from the percentage of completion. The implementation of learning is carried out through Cycle I and Cycle II based on the learning implementation plan.

This research's object is the social interaction and learning achievement of students (affective and cognitive aspects) of the applied learning.

\section{Acknowledgments}

The author would like to thank Vocational High School 1 Padang for the technical assistance to complete this research.

\section{REFERENCES}

[1] Amri, S., \& Ahmadi I, K. "Creative and Innovative Learning Process in the Classroom". Jakarta: Prestasi Pustakaraya, 2010, pp. 1-200.

[2] Ardi, Triyanto., et al, "Comparative Study of Learning Methods of STAD and TAI Equipped LKS Against Learning Achievement of Grade XI Students in Thermochemical Materials in SMA Negeri 8 Surakarta Year 2012/2013”. Journal of Chemical Education (JPK), vol. 2, no. 4, pp. 1-12, 2013.

[3] Fatimah, et al. "Implementation of Cooperative Learning Model TAI Equipped with Student Worksheets Based on Hierarchy Concepts To Improve Social Interaction And Student Learning Achievement In Redox Material. Jurnal Pendidikan Kimia, vol. 6, no.1, pp: 69-75, 2013.

[4] Hasanova, M. "Ways of Independent Development of Pedagogical Competencies of Students in Innovative Activity (The Study Case of Azerbaijani Students in Mathematics and Computer Sciences)". Universal Journal of Educational Research, vol 8, no. 9, pp.4163-4172, 2020. https://10.13189/ujer.2020.080942

[5] Janpla, S., Piriyasurawong, P. "The Development of an Intelligent Multilevel Item Bank Model for the National Evaluation of Undergraduates". Universal Journal of Educational Research. vol. 8, no. 9, pp. 4143-4150, 2020. https://10.13189/ujer.2020.080940

[6] Jatmiko, A., Wilujeng I., “Analysis Of Students' Social Skills On Cooperative Learning In Science education”. Jurnal Kependidikan, vol. 1, no. 2, pp. 240-252, 2017. doi: https://doi.org/10.21831/jk.v1i2.8408

[7] Miles, M. B. \& Huberman, A. M, “Qualitative Data Analysis. Terj. Rohendi. Jakarta: UI Press, 1995, pp. 1-350.

[8] Moeleong J. L. "Qualitative Research Methodology". Bandung: Rosdakarya Youth, 1995, pp. 1-670.

[9] Nneji "Impact of Framing and Team Assisted Individualized Instructional Strategies Student's Achievement in Basic Science in the North Central Zone of Nigeria”. Journal Knowledge Reviews, Vol. 23 No. 24, 2011.

[10] Dewi, Y.N., Masril, M., et al. "The Development of E-Module English Specific Purpose based on Computer Application for Vocational High School Students". Journal of Physics: Conference Series, 1364(1), 2019 
[11] Nuroh, E. Z., \& Mandarani, V. "The Use of Cooperative Learning Through Tai (Team Assisted Individualization) In Reading Comprehension”. Script Journal: Journal of Linguistics and English Teaching, vol. 3, no. 1, pp. 14-23, 2018. https://doi.org/10.24903/sj.v3i1.148

[12] Permendikbud RI, No. 59. (2014). Curriculum 2013 for $S M K / M A$

[13] Erdisna,, Ganefri,, Ridwan,, Efendi, R., Masril, M. "Effectiveness of Entrepreneur Digital Learning Model in the Industrial Revolution 4.0". International Journal of Scientific and Technology Research, Vol. 9, No. 3, pp. 5611-5616, 2020

[14] Purwanto, N. “Teaching Evaluation Principles and Techniques”, Bandung: PT Remaja Rosdakarya. 2002, pp.149.

[15] Rahmawati, Cici Putri., et al. "The Influence of Teams Assisted Individualization (TAI) And Learning Together (LT) Cooperative Learning Model on Learning Achievement Reviewed Students' Mathematical Skills on Mol Concept Subject Class X SMA Negeri 4 Surakarta School Year 2013/2014". Journal of Chemical Education (JPK), vol. 4, no. 1, pp. 1-12, 2015.

[16] Rejeki., et al. "Learning Team Assisted Individualization Equipped with Concept Map to Improve Student Learning Activities and Achievements.”. Jurnal Pendidikan Kimia Vol. 2 No.3, 2013.

[17] Rositawati, Dwi., et al, "The Use of TAI Learning Model Equipped with Media Card Problem to Improve Social Interaction And Learning Achievement in Basic Legal Materials And Mole Concept Class X SMA Negeri Kebakkramat Year Lesson 2014/2015”. Journal of Chemical Education (JPK), vol. 4, no. 4, pp. 26-33, 2015.

[18] Robert E. Slavin, "Cooperative Learning, Success for All, and Evidence-based Reform in education", Éducation et didactique, vol. 2, no. 2, pp. 149-157, 2008.
[19] Setiawan, et al. "Implementation of Cooperative Learning Model Teams Assisted Individualization To Improve Social Interaction And Student Learning Achievement In Hydrolysis Materials”. JPK: Journal of Chemical Education, Vol.4, No.1 pp. 97-103, 2015.

[20] Saminanto “Let's Practice Class Action Research. Semarang: Rasail Media Group, 2012, pp 3.

[21] Shillahaque, Galih Prismasari., et al, "Implementation of TAI Learning Model With Media Key-Relation Chart (KR-CHART) To Increase Student Curiosity and Learning Achievement in Solubility Materials And Solubility Results Students Grade XI MIA 1 SMA Negeri 5 Surakarta Year 2014/2015”. Journal of Chemical Education (JPK), vol. 4, no. 4, 2015.

[22] Suyadi. "Class Action Research Guide”. Yogyakarta: Diva Press, 2010, pp. 1-270.

[23] Sulistyaningsih, Eko., et al, "Implementation of Learning Method assisted individualization team (TAI) equipped with guided notes to improve the activities and learning achievement of Grade XI MIA Students in Chemical Equilibrium Materials at SMK Negeri 1 Sukoharjo School Year 2014/2015”. Journal of Chemical Education (JPK), vol. 4, no. 2, pp. 34-44, 2015.

[24] Syah, Fanny Firman., et al. "Influence of Model Team Assisted Individualization with Structure Exercise Method on Learning Outcomes". Journal of Chemical Education Innovation, vol. 8, no. 1, pp.13-23, 2014.

[25] Syaifuddin, M. Wahid, "Experimentation of TAI Cooperative Learning Model on Relationship And Function Subjects Reviewed from Students' Initial Abilities". Magistra Journal, vol. 8, no. 3, pp. 41-53, 2013.

[26] Tinungki, G. M, “The Role of Cooperative Learning Type TAI to Improve the Students' Mathematics Communication Ability in the Subject of Probability Theory”. Journal of Education and Practice, vol. 6, no.32, pp. 27-31, 2015. 